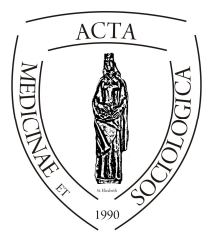

Acta Medicinae et

Sociologica (2019)

UNIVERSITY OF

DEBRECEN

Vol. 10. No. 28.

FACULTY OF

HEALTH

doi:

NYÍREGYHÁZA

\title{
The responsibility of higher education
}

\author{
Csók Cintia \\ Student, Institute of Educational Studies and Cultural Management University of Debrecen, \\ 4032 Debrecen, Egyetem tér 1.
}

\begin{tabular}{|c|c|}
\hline INFO & ABSTRACT \\
\hline $\begin{array}{l}\text { Csók Cintia } \\
\text { csokcintia@gmail.com }\end{array}$ & $\begin{array}{l}\text { Abstract. In our present work - based on Gabriella Pusztai, } \\
\text { Veronika Bocsi, Tímea Ceglédi (2016, eds.): A felsőoktatás } \\
\text { (hozzáadott) értéke [The value (added) in higher education] }\end{array}$ \\
\hline $\begin{array}{l}\text { Keywords } \\
\text { book review } \\
\text { higher education } \\
\text { efficiency } \\
\text { drop-out }\end{array}$ & $\begin{array}{l}\text { - we focus on the individual and institutional differences of } \\
\text { effectiveness, and on the scope of efficiency of the institu- } \\
\text { tions. The volume published within the framework of the } \\
\text { Higher education \& Society book series of Center for Higher } \\
\text { Education Research \& Development (University of Debre- } \\
\text { cen, Hungary) focuses primarily on the comparative ap- } \\
\text { proach, complex approach, and methodological challenges } \\
\text { of institutional impact, as well as the eclectic nature of the } \\
\text { topic from a student and institutional perspective. }\end{array}$ \\
\hline $\begin{array}{l}\text { Kulcsszavak } \\
\text { recenzió } \\
\text { felsőoktatás } \\
\text { eredményesség } \\
\text { lemorzsolódás }\end{array}$ & $\begin{array}{l}\text { A felsőoktatás felelössége. Jelen munkánkban - Gabriella } \\
\text { Pusztai, Veronika Bocsi, Tímea Ceglédi (2016, szerk.): A } \\
\text { felsőoktatás (hozzáadott) értéke címü tanulmánykötet alap- } \\
\text { ján - az eredményesség egyéni és intézményi különbségei- } \\
\text { re fókuszálunk. A Debreceni Egyetem Felsőoktatási Kutató } \\
\text { és Fejlesztő Központ Felsőoktatás \& Társadalom sorozatá- } \\
\text { nak keretében megjelent kötet elsősorban az intézményi } \\
\text { hatás komparatív meg-közelítésével, komplex szemléleté- } \\
\text { vel és metodikai kihívásaival foglalkozik, valamint a hall- } \\
\text { gatói és intézményi nézö-pontok oldaláról is rámutat a } \\
\text { téma sokszínủségére. }\end{array}$ \\
\hline
\end{tabular}

Ez a recenzió a 123847 számú projekt a Nemzeti Kutatási Fejlesztési és Inno-vációs Alapból biztosított támogatással, a K_17 pályázati program finanszírozásában valósult meg. Továbbá az Emberi Erőforrások Minisztériuma ÚNKP-18-2 kódszámú UUj Nemzeti Kiválóság Programjának támogatásával készült. 
In 2017, a number of research and development initiatives have been launched to reduce drop-out in public and higher education in Hungary. Educational researchers strive to explore the social and organizational factors that can play a role in student dropouts and try innovative methods that reduce the risk of exit without qualification. In our previous review about the book of Gabriella Pusztai, Klára Kovács (2015, eds.): Ki eredményes a felsőoktatásban? [Who is successful in higher education?], we wrote about a previous research of Center for Higher Education Research \& Development - Hungary, which sought to find out the factors that could contribute to student achievement and thus may be "antidotes" of dropout. In our previous book review, following the content structure of the volume, we dealt with the approaches of academic achievement of students, institutional and non-institutional support factors, and the career opportunities of special student groups (Csók 2017).

In our present paper, in response to a new phase in the work of the research team, we focus on the individual and institutional differences of effectiveness, and on the scope of efficiency of the institutions. In the book of A felsöoktatás (hozzáadott) értéke [The value (added) in higher education], we can read first the introductory writing of Gabriella Pusztai, Veronika Bocsi and Tímea Ceglédi. The editors draw attention to the fact that, due to the expansion and diversification of higher education, the world of higher education has become quite diverse, the functioning of the institutions has changed, the functions have been expanded and, as a result, institutional impacts are also different. The question arises as to what components explain the individual and organizational differences of effectiveness. The volume published in the framework of the Felsöoktatás \& Társadalom [Higher education \& Society] series of Center for Higher Education Research \& Development (University of Debrecen, Hungary) focuses primarily on the comparative approach, complex approach, and methodological challenges of institutional impact, as well as the eclectic nature of the topic from a student and institutional perspective. The editors divided the studies into four major chapters based on these.

In the chapter entitled Az intézményi hatás komparativ megközelitésben [Institutional Effect in a Comparative Approach], Veronika Bocsi and Tímea Ceglédi point out based on the analysis of focus group interviews - in their study of Features of institutional effects - from the viewpoint of students and experts, that students would consider it important to get more detailed information on courses of higher education, more useful theoretical knowledge, practice orientation and effective education organization in order to prevent their own under-motivation and burn-out. In addition, they highlight the benefits of wider sport facilities, and the leisure time programs that help to enhance group cohesion. Additionally, interviewees would require for their successful student socialization - at the same time as they start their higher education studies - a conscious introduction to their new living space (for example, with the help of a senior year student).

The following three studies focus on measuring value added at different educational levels. Krisztián Széll, Katinka Bacskai and Szilvia Borbély - Value added in public education - approaches the institutional impact from the aspect of public education, and they present the results of the educational value-added concept with a summary of literature research. Edina Malmos and Ibolya Markóczi Revákné's study- 
CLA - Experiments for measuring the value added in higher education - approaches the issue from the aspect of higher education and emphasizes the critical analysis of the Collegiate Learning Assessment (CLA) method. Among the positive aspects of CLA, it should be noted that using it will also be possible to create aggregate institutional rankings that can encourage universities/colleges to achieve better performance. The up-to-date version of CLA is CLA+, of which we can read more in Roger Benjamin's study called Leveling the playing field from college to career ${ }^{l}$. Furthermore, the president of the Council for Aid to Education, which is a national non-profit organization in New York City, draws attention to the serious difficulties of the higher education sector, its financial problems, the shortcomings in access to higher education, and unfavourable institutional retention and graduation rates. Based on the author's analysis, it emerges that the most urgent task is solving market anomalies between students and employers. In addition, it is crucial to increase equal opportunities because when a group feels that they do not start with the same opportunities, they become uncertain and will not fight further. This statement by Benjamin in exploring the causes of dropping out can be a starting point for researchers.

In this chapter, Andrea Homoki's study is the last one: The reception of resilience in the national educational science research. Based on the presented research, risk factors that may play a role in drop-out (e.g. disadvantageous situation, serious family conflicts, deviance in the family) are outlined before us. At the same time, we can review the protective factors that promote school success (e.g. parental, social and educational support, sports). This study also points out that in the supporting interventions, besides the individual development, the refinement of the connection systems is becoming more and more important.

In the chapter of Komplex megközelitések, módszertani kihívások [Complex Approaches and Methodological Challenges], Timothy Rodgers: Measuring value added in higher education: A proposed methodology for developing a performance indicator based on the economic value added to graduates study can be read in Hungarian translation. The author demonstrates the significance of this work by showing that he is open to develop a new methodological experiment, a performance index proposal. After an international outlook, it is worth focusing on the work of István András Kun's economist (The appearance of the institutional effect on the wage gap), who has made extensive analyses about economic higher education in Hungary: he made estimates with t-tests and ANOVA in univariate cases, and with linear regression in multivariate models.

In addition to the innovation methodical experiments, we find novel results for students with different social backgrounds as well. In the work of Gabriella Pusztai The institutional effect and its sources - she created student status groups and classified the children of parents with primary or skilled education living in villages, with secondary school education living in small towns, and with higher education living in cities. During the research of the author, she found that during the years of higher

\footnotetext{
${ }^{1}$ In the volume, studies translated from foreign language into Hungarian can be read, of which, the study of Roger Benjamin: Leveling the playing field from college to career is the first one.
} 
education, parental contact and attention are considered priority resources and they greatly increase the possibility of getting into the scope of more successful students, which she identified in her earlier work as family social capital (Pusztai 2009, Pusztai 2016). This result of Pusztai should also be emphasized because, in order for the success of students, the strengthening of the relationship between parents and higher education should be considered, and parents should be an active partner. Pusztai additionally examines higher education social capital as well (Pusztai 2015). According to her, the institutional effect of higher education is realized through the mediation of institutional composition, institutional relations and institutional networks, and their effect is also compared in a multivariate model. According to her results, among the relational factors of the institutional context, study-intellectual intergenerational contacts (such as Scientific Student Conference and research team membership) are the strongest and most stable institutional support factors. In addition, we can read in detail about the institutional impact of higher education, as well as in the paper of Veronika Bocsi: Shift to the intellectuals' life? The analysis of possible potential effects. It appears as a research question at Bocsi, whether the neutralizing influence of disadvantageous situation of university existence can be captured. The study of Roland Hegedüs: Disadvantaged students and their forecasted chances at the labor market further enhances our knowledge of disadvantaged students by analysing data on average results of graduates, average job search time, and labour market status based on the Hungarian Graduate Career Tracking System. Finally, we would like to highlight here the statement of Klára Kovács, Karolina Eszter Kovács and Beáta Erika Nagy (Institutional effects in students' health conscious behavior) with an indicative value, according to which students with higher status usually study in courses where the requirements are high and consequently they are less active than what would be expected based on their status. According to the authors, this is dangerous because they would be able to relieve the stress caused by strong performance pressure through sport.

The lesson of the last study of the chapter from Hajnalka Fényes (Gender differences in higher education efficiency and the effect of the faculty composition) is that the gender composition of the faculty can affect the effectiveness of women and men. It is apparent from the analyses of Fényes that the advantages of men can be demonstrated mainly through so-called academic achievements (conference presentations, participation in talent development programs and scholarships, demonstrative scholarships ${ }^{2}$, republic scholarships ${ }^{3}$ ).

In the chapter of Hallgatói nézöpontok [Student aspects], we can read about students in different fields of study. Two articles focus especially on the teacher training. According to Lilla Koltói (Becoming a teacher - research of the basic school teacher training students' professional identity), the key task of higher education is to help students to succeed, to support professional socialization and to develop pro-

2 In Hungary, students who earn demonstrative scholarship can get involved in the educational, researching and administrational work and in other tasks at their department.

${ }^{3}$ In Hungary, students with outstanding performance at the professional section besides their prominent studying results can apply for republic scholarship. 
fessional identity. Her research involves three different ways (spontaneous selfpresentations, collective self-esteem and work associations) of looking at the questions to be examined. In the work of Emese Beáta Berei (Teacher training students' attitudes towards their marginalized peers), teacher candidates are also centered from the perspective of inclusive student attitudes. However, from the paper of Krisztina Sebestyén (Relationships between students' social background and language proficiency exams studying in different study fields), we should highlight the students of social sciences who, based on the author's analysis, mostly belong to low-educated wealthy urban people and low-educated poor rural people. In view of these data, it is not surprising that they have unfavourable indicators regarding foreign language skills and foreign mobility with additional financial expenditures.

Two studies highlight particular motifs as well. Hajnalka Fényes and Valéria Markos (The effect of the institutional environment on volunteering) draw attention to the fact that volunteering can be interpreted as a performance index as well. Higher education institutions and faculties should therefore take greater responsibility in motivating students and promoting their willingness to volunteer (e.g. providing information on opportunities involving career offices and integration into curricula). In their work Religiosity and health. Religiosity as a social protection factor Sándor Hodossi and Zsuzsanna Márkus showed that religion and the practice of religion can mean resources for the individual.

Ágnes Engler - uniquely in the volume - formulated her study questions regarding part-time students (Value added in the part-time students' interpretation). The author's work based on mixed methodology includes quantitative and qualitative techniques as well. Among the results, one must highlight that there is a strong correlation between efficiency and satisfaction. Furthermore, the student observations point to interesting components. On behalf of the respondents, practice orientation, incorporating their experience into classroom discourses, better contact with instructors and professional conversations all appear as requirements. In addition, proposals are made to develop the qualification system for teaching staff and to facilitate the management of study affairs.

Imre Labancz and Nóra Barnucz put the driving force of XXI. century into focus, which includes information and communication devices (An experiment for studying the effect of ICT in higher education). In their statistical analyses, they explore ways of preparing for exams, the most effective learning methods, the daily internet time, and the frequency of Internet activities related to higher education in Partium, Subcarpathia in Ukraine and the Northern Great Plain region of Hungary. It can be stated as a lesson that higher education institutions should place greater emphasis on the more intensive use of ICT tools, as well as on the possibilities of using and developing digital competences.

The first three studies in the last chapter of Intézményi nézöpontok [Institutional aspects] provide a deeper insight into the world of colleges for advanced studies. The literature review of Tímea Ceglédi, Andrea Bordás and Katalin Kardos (From one of the two or from zero of the three? Institutional effect of colleges for advanced studies) points to the following positive effects of colleges for advanced studies: higher value added, more personal and more meaningful student socialization oppor- 
tunities, potential of emerging learning communities, and compensation for disadvantage. According to the authors, students at colleges for advanced studies have so many different opportunities, which are an advantage in both the academic and the labour market. After a review of research on topic, we can get an insight into some church-maintained Roma colleges in Northern Great Plain region and Southern Great Plain region reading the case studies of Teréz Jenei and Judit Kerülö (The development of personal and social competences in the Nyiregyháza Evangelical Roma College for Advanced Studies), and Csaba Jancsák (Contribution of Christian Roma College of Szeged to higher education in a value sociology approach).

With regard to institutional aspects, new findings are presented in the last two studies of this chapter about students studying in different training. In the work of Gergely Kováts, Sára Csillag, and Anna Laura Hidegh: Critical management education with the subjects of Organizational Theories and Alternative Human Resources Management, the possible institutional impact of two courses taught in MSc in Management and Leadership at the Corvinus University of Budapest are examined in the light of student reviews. Finally, Adrienn Fekete (Foreign language learning. Why and how? First-year foreign language teacher majors' foreign language learning objectives and attitudes towards intercultural communicative competence development in the language classroom) analyses the foreign language learning objectives, the attitudes of intercultural communicative competence and the relationship between these two among first-year foreign language teacher students.

Regarding the studies it can declare the book called A felsöoktatás (hozzáadott) értéke [The value (added) in higher education] is a scientific work possessing a various supply of methodology on the institutional impact of higher education applying a regular, wide-ranging approach. Alongside the education researchers and higher education politicians, it can be useful to all the students, who are interested in what are the institutional factors that can help successful student life and successful integration into the labour market after graduation. Furthermore, I can recommend the book for all the persons in higher education, because the analysis goes through of the mode of action of the institutional environment, which may show directions regarding to the rate of dropout from the higher education.

\section{References}

1. Csók Cintia (2017): Eredményesség felsőfokon, avagy a siker titka. Pusztai Gabriella és Kovács Klára (2015, eds.): Ki eredményes a felsőoktatásban? címü kötet recenziója. PedActa (7), 2: 93-96.

2. Pusztai Gabriella (2009): A társadalmi tőke és az iskola: Kapcsolati erőforrások hatása az iskolai pályafutásra. Budapest, Új Mandátum Kiadó.

3. Pusztai Gabriella (2015): Mire jó a társadalmi tőke koncepció a felsőoktatáskutatásban? In: Kozma Tamás, Kiss Virág Ágnes, Jancsák Csaba, Kéri Katalin [eds.], Tanárképzés és oktatáskutatás. Debrecen, Magyar Nevelés- és Oktatáskutatók Egyesülete (HERA). 467-484. 
4. Pusztai Gabriella, Bocsi Veronika, Ceglédi Tímea (2016, eds.): A felsőoktatás (hozzáadott) értéke. Nagyvárad-Budapest, Partium Könyvkiadó-Personal Problems Solution-Új Mandátum Könyvkiadó.

5. Pusztai Gabriella, Kovács Klára (2015, szerk.): Ki eredményes a felsőoktatásban? Nagyvárad-Budapest, Partium Könyvkiadó-Personal Problems SolutionÚj Mandátum Könyvkiadó.

\section{Csók Cintia}

A Debreceni Egyetem Gyermeknevelési és Felnőttképzési Karán szerzett szociálpedagógus diplomát. Jelenleg a Debreceni Egyetem Bölcsészettudományi Kar neveléstudomány mesterszakán folytat tanulmányokat. 2017-ben az Országos Tudományos Diákköri Konferencián első helyezést ért el. A 2018/2019-es tanévben az Új Nemzeti Kiválóság Program ösztöndíjasa. 